\title{
SYNONYMIC RELATIONSHIPS OF ESTONIAN SIMILES RELATED TO THE CONCEPT KIIRESTI
}

\section{Katre Õim}

\begin{abstract}
The article discusses a small number of Estonian similes connected with the concept kiiresti ('quickly', 'fast'), used to describe physical bodily movement as well as mental movement associated with cognition. Most of the analysed similes characterise dynamic progressive or non-progressive situations; the relationship between the progress of a situation and viewpoint, expressed in these similes, may be defined or undefined. Most of these phrases are understood through metaphoric transfer: the source domain often being an animal or a characteristically fast moving natural phenomenon, while the target domain is mostly a human. The article describes systematic semantic projections that might be regarded as manifestations of naïve physics in language. The presented semantic variants clearly represent the characteristic tendencies of metaphoric transfer - for example, while speaking about mental processes through physical processes or conceptualising the abstract through the concrete.
\end{abstract}

Keywords: simile, cognitive metaphor theory, metaphor, conceptual domain, cognitive domain, projection, mapping.

The article deals with similes which in (the Estonian) phraseology are of relatively stable structure and occur in quite large numbers. The main aspects of the expressions that I will discuss in the following are associated with the concept kiiresti 'rapidly', 'quickly', 'fast'. The aim of the article is, on the one hand, to explicate the extent and way how the concept functions in the meaning of the expression(s), whether the expressions share common semantic features, which figures are used for expressing the same or similar referential content, and, on the other hand, which conceptual domains a figure of speech comprises. In explaining the trope formation mechanisms of similes I have proceeded from the cognitive theory of metaphor, which operates with concepts like mapping, projection, conceptual domain and domain of experience, source and target domain, etc. The theory of metaphor was introduced by George Lakoff and Mark Johnson already in 1980, and considerably changed the conventional understanding of the functioning of meta- 
phor (see Lakoff \& Johnson 1980). Lakoff and Johnson claim that (1) metaphor is not a matter of words, but of concepts; (2) the aim of metaphor is to allow us to better comprehend certain concepts, and not poetic or aesthetic expression; (3) metaphor is often not based on similarity; (4) metaphors are freely used in everyday conventional language not only by exceptionally talented speakers but by ordinary people; (5) metaphor is not excessive, although an enjoyable linguistic embellishment, but unavoidable process of human thought and discourse (see e.g. Kövesces 2002: VIII; see also articles in Estonian in Krikmann 2002, 2003; H. Öim 1997; Vainik 1995; Tragel 2003).

The expressions and sentences analysed in this article are borrowed from the database of Estonian phrases of the Estonian Literary Museum, a corpus of material collected mainly at the end of the 19 th and the 20 th century.

\section{THE CONCEPT KIIRESTI IN SIMILES}

The concept kiiresti appears in the meanings of a number of similes. Such expressions centre on processes in time, also to personal human characteristics: their purpose is to characterise the change in the location of object or subject or a course of events intensively and within a short period of time, a person's tendency to complete all his or her actions quickly, or his or her restless nature, and assessment. It is characteristic of similes that the expressions demonstrate the maximum intensity (of speed) relative to standard norm - the degree of the characteristic is identified with something that is considered the typical bearer of the maximum degree (Metslang 1997: 148). As expected, most often the attention is turned to a person who is moving quickly, disappearing from sight, acts rashly and negligently, is irascible, etc. - in other words, the speaker's attitude towards the person $\mathrm{s} / \mathrm{he}$ describes is clearly negative. I have grouped similes with sufficient overlapping of meaning, equal in their textual use, under synonymic lists (see Apresyan 2000: X ff.; A. Õim 1991: 4). The similes discussed here are partial rather than full synonyms (see A. Õim 2002: 309-311; see also Akhmanova 1969), although fully synonymic similes quite often coincide on the semantic (the lexical meaning of a language unit), grammatical (the 
morphology of a language unit) and on the syntactic level (the syntactic role of a language unit in a sentence). In principle, all these similes could be regarded as units of subcategories in synonymic relationships branching on the basis of several characteristics and grouped under the category kiiresti (see A. Õim 2002: 294, 295). For example, similes on starting of movement: nagu nöörist 'like from a string', justkui tikust tuli 'came like fire from a match', nagu püssist 'like from a handgun'; on coming, arrival: tuleb nagu püssipauk 'comes like a gunshot', tuleb äkki nagu piksenool 'comes suddenly like a flash of lightning', nagu välk selgest taevast 'like a lightning from blue sky'; on moving forward: jookseb nagu jänes 'runs like a hare', läheb kui tuli sõordu mööda 'goes like a wildfire on the field', läheb nagu lingukivi 'goes like a slingshot'; on moving on a spot, back and forth or from one location to another: justkui tuulispask 'like a whirlwind', keevad kui sipelgad 'boil like ants', nagu uba keevas katlas 'like a bean in a boiling kettle'; on diminishing of something: lähevad nagu soojad saiad 'go like warm buns', sulab nagu kevadine lumi 'melts like spring snow'; on ending: nagu tilk vett kuumale kerisele 'like a drop of water on a hot oven', läks kui kerisele 'went like on a hot stove', nagu koera kaelas vorst 'like a sausage around a dog's collar'; on progress: nagu nuusata 'like blowing the nose', käib nagu käkitegu 'goes like making a cake' / 'like a piece of cake', käib nagu kaljapudi laste käes 'goes like kvass powder at the hands of children'. This also explains why the synonymic list of similes like jookseb kui hobune, jookseb kui kits, jookseb nagu metskits, jookseb nagu põder 'runs like a horse /a goat / a wild deer / a moose' does not include similes describing movement in any other way, such as: venib kui härg 'drags like an ox', venib nagu sandi kelguohelik 'drags like a cripple's sledge string', loivab kui hüljes 'shambles like a seal' meaning 'to move slowly'; astub nagu kass märga maad mööda 'steps like a cat on a wet ground', i.e. 'to watch the step', 'to step carefully'. This would, of course be possible, if we take motion as the main category that includes subcategories like MOVING SLOWLY, MOVING QUICKLY, etc. That the main category is rarely signified with comparative phrases appears to be a feature characteristic of similes.

My analysis comprised 158 similes, characterised by the semantic concept KIIRESTI, whereas the meaning of 26 of these similes includes two or more content aspects of the concept. According to 
phraseological synonymic relations the material discussed here can be categorised into similes describing fast movement, action, activity, talking, or irritation. Similes forming synonymic lists tend to group into synonymic subcategories. A synonymic list may, for example, consist of the following expressions (a) usin nagu mesilane 'busy as a bee', usin nagu sipelgas 'diligent like an ant', kui kihulane 'like a midge', kui ämblik vee peal 'like a spider on water', nobe kui päästlane 'swift like a swallow'; teeb tööd kui tihane 'works like a tomtit', nagu käblik 'like a wren', nobe kui västrik 'swift like a wagtail', virk nagu nirk 'hard-working like a weasel', väle kui hirv 'quick like a deer', ole atses kui koer linnu taga 'is at work like a dog hunting a bird', nagu putsai 'like a feather'; käivad nagu kerilauad 'move like swifts', terane kui nõel 'sharp as a needle', erk kui koera kirp 'agile as a dog flea', nagu kirp koera perses 'like a flea in a dog's arse', virk kui kutsika sitt 'swift like a puppy's dung', nagu kurg läheb korra puusse ja murrab sä̈̈reluu 'rushes like a stork against the tree and crushes shinbone', nagu juut naise man 'like a Jew with a woman', nagu tuul 'like wind', justkui tuulispask 'like a whirlwind', kärme kui tulehakatis 'fast like kindling', nagu tulesäde 'like a firespark'; (b) läheb nagu lepase reega 'goes like on an alder sleigh' / 'goes swimmingly', läheb kui õlitatult 'goes as if greased', läheb nagu masinaga 'goes like with a machine', kui lõhn 'like a smell', käib nagu käkitegu 'like making a cake' / 'like a piece of cake', nagu nuusata 'like blowing the nose', nagu nohu 'like a running nose', läheb nagu nalja 'goes like fun', käib nagu kaljapudi laste käes 'goes like kvass powder at the hands of children'; töö nagu mäda 'work like rot'; läheb kui lähkritöö 'goes like keg-work'; nagu kangast veab 'like pulling cloth' - all these similes mean 'something is doing something fast or quickly'. Here synonym groups (a) and (b) are distinguished on the basis of the presence of the active controlling agent in the situation. In the first group the synonyms mean that a person is doing something quickly, is swift or diligent, in the second group it is the process or action that goes smoothly and quickly.

Comparing the meanings and aspect of similes, and the speaker's evaluation, we may generalise that the phrases discussed here describe the situations in the following table. 


\begin{tabular}{|c|c|c|c|c|}
\hline & \multirow{2}{*}{$\begin{array}{l}\text { Meaning of } \\
\text { simile }\end{array}$} & \multicolumn{3}{|c|}{$\begin{array}{c}\text { Situation description and speaker's } \\
\text { attitude }\end{array}$} \\
\hline & & Positive & Negative & Neutral \\
\hline \multirow{6}{*}{ 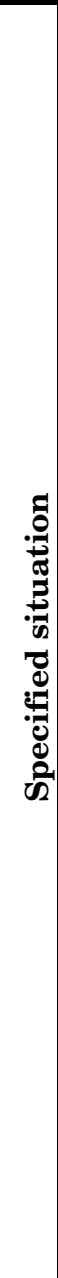 } & $\begin{array}{l}\text { 'someone starts } \\
\text { moving quickly } \\
\text { and } \\
\text { unexpectedly' }\end{array}$ & & $\begin{array}{l}\text { A person jumps } \\
\text { up and starts } \\
\text { moving quickly } \\
\text { and unexpectedly }\end{array}$ & \\
\hline & $\begin{array}{l}\text { 'someone or } \\
\text { something } \\
\text { appears, comes, } \\
\text { arrives quickly, } \\
\text { unexpectedly' }\end{array}$ & & \begin{tabular}{|l} 
- a person \\
suddenly appears, \\
comes; \\
- arrival of \\
unexpected bad \\
news
\end{tabular} & \\
\hline & $\begin{array}{l}\text { 'someone leaves, } \\
\text { disappears } \\
\text { quickly }\end{array}$ & $\begin{array}{l}\text { Parasites, } \\
\text { insects are } \\
\text { quickly } \\
\text { repelled }\end{array}$ & $\begin{array}{l}\text { - a person leaves, } \\
\text { disappears } \\
\text { without a trace; } \\
\text { - an animal } \\
\text { suddenly } \\
\text { disappears }\end{array}$ & $\begin{array}{l}\text { a person } \\
\text { marries } \\
\text { hastily }\end{array}$ \\
\hline & $\begin{array}{l}\text { 'something ends } \\
\text { quickly' }\end{array}$ & $\begin{array}{l}\text { Pain relieves } \\
\text { quickly, fear } \\
\text { passes in a } \\
\text { moment }\end{array}$ & $\begin{array}{l}\text { food runs } \\
\text { quickly out; } \\
\text { money, fortune, } \\
\text { etc. is quickly } \\
\text { spent: } \\
\text { - an event passes } \\
\text { quickly } \\
\end{array}$ & \\
\hline & $\begin{array}{l}\text { 'someone quickly } \\
\text { completes } \\
\text { something' }\end{array}$ & $\begin{array}{l}\text { Work, activity } \\
\text { is quickly and } \\
\text { effortlessly } \\
\text { completed }\end{array}$ & & \\
\hline & $\begin{array}{l}\text { 'someone is } \\
\text { easily irritated' }\end{array}$ & & $\begin{array}{l}\text { A person turns } \\
\text { quickly angry, evil }\end{array}$ & \\
\hline
\end{tabular}

Table 1. continues on reverse. 


\begin{tabular}{|c|c|c|c|c|}
\hline & $\begin{array}{l}\text { 'someone or } \\
\text { something } \\
\text { moves quickly } \\
\text { forward' }\end{array}$ & $\begin{array}{l}\text { A person moves } \\
\text { on vigorously, } \\
\text { well }\end{array}$ & $\begin{array}{l}\text { - a person, an animal } \\
\text { moves too quickly, } \\
\text { rushes; } \\
\text { - a car moves too fast; } \\
\text { - gossip is spread fast }\end{array}$ & $\begin{array}{l}\text { - a person, an } \\
\text { animal runs } \\
\text { quickly; } \\
\text { - fire burns, } \\
\text { spreads } \\
\text { quickly }\end{array}$ \\
\hline & $\begin{array}{l}\text { 'someone moves } \\
\text { quickly on a } \\
\text { spot, back and } \\
\text { forth or from one } \\
\text { location to } \\
\text { another' }\end{array}$ & & $\begin{array}{l}\text { A person fidgets on a } \\
\text { spot, moves back and } \\
\text { forth } \sim \text { from one place to } \\
\text { another, is restless and } \\
\text { uneasy }\end{array}$ & \\
\hline & $\begin{array}{l}\text { 'something runs } \\
\text { out, wears out } \\
\text { quickly' }\end{array}$ & $\begin{array}{l}\text { Something good } \\
\text { is consumed } \\
\text { quickly and in } \\
\text { large amounts }\end{array}$ & $\begin{array}{l}\text { - food, money, fortune, } \\
\text { etc. is spent, runs } \\
\text { quickly out; } \\
\text { - burning happens too } \\
\text { quickly }\end{array}$ & $\begin{array}{l}\text { Time passes } \\
\text { quickly }\end{array}$ \\
\hline & $\begin{array}{l}\text { 'someone } \\
\text { completes } \\
\text { something } \\
\text { quickly' }\end{array}$ & $\begin{array}{l}\text { - a person is } \\
\text { swift, quick and } \\
\text { diligent; } \\
\text { - a work, } \\
\text { activity } \\
\text { progresses } \\
\text { quickly, well } \\
\end{array}$ & $\begin{array}{l}\text { - a person acts too } \\
\text { rashly, too quickly, } \\
\text { without thinking; } \\
\text { - people, animals, } \\
\text { things are replaced } \\
\text { after excessively short } \\
\text { periods of time }\end{array}$ & \\
\hline & $\begin{array}{l}\text { 'someone is busy, } \\
\text { has much to do' }\end{array}$ & & $\begin{array}{l}\text { - a person is busy, has } \\
\text { much work /things to } \\
\text { do; } \\
\text { - a lot of hard work } \\
\text { requires quick action }\end{array}$ & \\
\hline & $\begin{array}{l}\text { 'someone speaks } \\
\text { fast' }\end{array}$ & & $\begin{array}{l}\text { - a person speaks } \\
\text { quickly and } \\
\text { confusingly; } \\
\text { - a person speaks } \\
\text { quickly and much; } \\
\text { - too much talk comes } \\
\text { too fast }\end{array}$ & \\
\hline & $\begin{array}{l}\text { 'someone is } \\
\text { quickly and } \\
\text { easily angered' }\end{array}$ & & $\begin{array}{l}\text { A person is irascible, } \\
\text { evil }\end{array}$ & \\
\hline
\end{tabular}




\section{SEMANTIC CROSS-DOMAIN MAPPINGS}

The similes discussed here are generally understood through metaphoric variations, where one conceptual domain is mapped, i.e. partially projected to a different conceptual domain, so that the second domain is understood in terms of the first domain. The mapped domain is called source domain and the domain where the source domain is mapped is called target domain. For instance, knowing the structure of metaphor LIFE IS A JOURNEY means knowing a number of correspondences between the two conceptual domains of life and journeys, such as these (see Lakoff \& Tuner 1989: 3, 4):

SOURCE
Traveller
Destinations
Routes
Impediments to travel
Guides
The distance travelled
Landmarks
Crossroads
Provisions

TARGET
the person leading a life
his purposes
the means for achieving purposes
difficulties in life
counsellors
progress
things you gauge your progress by
choices in life
material resources and talents

The synonymic lists discussed here manifest the different solutions for describing /characterising analogous situations. In other words, one and the same target concept is understood via several different source concepts, for example, on a person's movement:

jookseb nagu põder 'runs like a moose', nagu tulesäde 'like a fire spark', nagu tuul 'like wind', kui lõhn 'like smell', nagu välk 'like a flash of lightning', väle nagu hiir 'swift like a mouse', liigub nagu kobe konn 'moves like a strong toad', läheb nagu lingukivi 'goes like a slingshot', nagu putsai 'like a feather', läheb nagu lennates 'goes like in flight', laseb nagu ratsahobusega 'goes /carries on like on a racehorse', läheb kui liblikas 'goes like a butterfly', laseb nagu lukussepp 'goes / carries on like a locksmith', kihutab nagu hobusevaras 'rushes like a horse thief', läheb kui eesenbaan 'goes like a train'.

As expected, the source domain corresponding to the generally human-centred target domain of a metaphor is often an animal, and 
fairly often also a phenomenon of nature that is characteristically quick, etc. Thus it is evident that in describing most of the situations included in Table 1 . we may very well proceed from the same source concept, such as, for example, fire: Jusku tikust tule tsiuhh! 'Swoosh! like fire from the match', nii ku sina ütled, nii tema läheb, ajaviitmist pole 'as you say, he goes - no spending time'; Erk hobune on, öeldaks ka, läheb kui tulepisu 'It's an agile horse, goes like a fire spark'; See uudis käis läbi kut kulutuli 'The news spread like wildfire'; Ta um ku üts tulekipin kohki paigal ei püsü 'He is like a fire spark, cannot stay still'; Erk ja virk ku tulesäde 'ta on täitsa usin, krips-kraps siin ja sääl' 'Quick and swift like a fire spark 'he is quite diligent, snip-snap here and there"; Minu poig om kui tulepirand 'My son is like a fire chip'; Justkui tuli kadajepuhman, öeldi naise kohta, kes palju ja ruttu kõneles, keda kutsuti sädemetädiks 'Like fire in juniper bush, the woman was called; who spoke much and quickly, was called Lady Spark'; Ossa ime, ku ütled sõna, nagu ale lääp põlemä 'äkilise inimese kohta' 'Oh boy, when you say a word, he burns up like wildfire 'about some irascible person'; Sii om kärk ja erk ku üits tulepisu kunagi 'She/he is as spry and nimble as a fire spark'. Analogously, in describing physical movement/activity as well as mental processes the source domain of a metaphor may be air (in the general sense of the word), cf.: Läheb nii kut tuulispask, hobune oli nii peru 'Goes like a whirlwind, the horse was so wild' meaning 'the person moves quickly forward'; Nuur hobõnõ, laapsa samm, versta kaosõ nigu lõhn 'Young horse, with vigorous step, versts pass like a smell' - 'the animal moves quickly forward'; Salt nigu piir sõglan, ei püsü paigal 'You are like a bad smell in a sieve, cannot stand still' - 'the person moves quickly on a spot, back and forth or from one place to another'; Taa tütruk om neil hirmus kräpe egäle asjalõ, ma peije aru, et kusma koti vankrillü saa, ku manu karas, oll kott vankrin nigu lõhn 'That girl is terribly spry at anything, I was just thinking how to get my bag on the carriage, when she jumped forward, the bag was on the carriage like a smell' - 'the person does something quickly'; Kiä sääntse väega tulitseide värkkega ja äkilitse omma, siis üldäs, et tuu lätt nigu tuulepass vai kadajekõrbeja 'When someone is fiery and easily angered, then people say that s/he goes like a whirlwind or juniper fire' - 'a person is quickly and easily angered on anything'. 
According to Zoltán Kövecses (2000: 79 ff.) most typical source domains characterise more than one target domain. Hence the question is about the scope of metaphor, i.e. the total range of target domains to which a source domain can be applied. Kövecses illustrates it with the example of 'building', which is applied to theories, but also to relationships, career, companies, economic systems, social groups, life. All these target domains are in some sense similar to each other, all are, one way or another, complex abstract systems, i.e. non-material domains with numerous interactive complex elements. The sc. specific-level metaphors THEORIES ARE BUILDINGS, RELATIONSHIPS ARE BUILDINGS, CAREER IS A BUILDING, COMPANY IS A BUILDING, ECONOMICAL SYSTEMS ARE BUILDINGS, SOCIAL GROUPS ARE BUILDINGS, LIFE IS A BUILDING constitute a generic-level metaphor COMPLEX ABSTRACT SYSTEMS ARE BUILDINGS. Different conceptual metaphors about 'air', such as A PERSON IS A WIND; A PERSON or A THING IS A SMELL; ACTIVITY IS A SMELL; A PERSON IS A SOUND; A MESSAGE, NEWS IS A SOUND, etc. may constitute a generic-level metaphor DYNAMIC SITUATION IS MOTION OF AIR. All these metaphors are bound to a finite number of characteristics of a dynamic situation, such as dynamic force and speed of motion or action. They have the main meaning focus, which is established on the central knowledge about an entity or event in a particular community of language. In other words, each source domain emphasises one or more aspects of target domain - each source domain, characterising the target domain it is applied to, is set to play a specific role. The target domain thus inherits the main meaning focus of the source domain (Kövecses 2000: 82). The main meaning focus of the metaphor DYNAMIC SITUATION IS MOTION OF AIR can be understood through the following different specific-level metaphors or mappings.

\section{1. 'Wind' as source domain of metaphors}

The metaphoric source domain of the following similes is 'wind', i.e. 'motion of air' relative to the surface of the Earth.

- When the source domain of a metaphor is a person or an animal, moving quickly forward or on a spot, back and forth, from one place to another, or who leaves some place, disappears quickly, then such 
similes can be understood through the mapping THE SPEED OF THE MOTION OF A PERSON AN ANIMAL IS THE SPEED OF THE MOTION OF AIR: Villigä Aadi kihut ratsala tiid mü̈̈d̈̈ nigu tuul 'Villigä Aadi rode by along the road like wind'; Käid suure ajoga ninda kui tuulispask, ei jõle äärt ei ôtsa senel 'You rush like a whirlwind, there's no end to it'; Mind nägi iemalt, kadus kui tuul 'Saw me from the distance, and disappeared like wind'. The characteristic aspects of the target domain that the source domain emphasises are great/excessive speed, restlessness, impatience, possibly also danger: Läheb nii kut tuulispask 'goes like a whirlwind', hobune oli nii peru 'the horse was so wild', or certain lightness: kadus nagu udutuul 'disappeared like a foggy wind'. In the sentence Nigu tuline tuul ikke tuhatkuuma mäest alla 'Like fiery wind down the mountain' the meaning of the adjective tuline 'fiery' functioning as an attribute may be regarded as the result of the variation 'with high temperature' > 'intense, forcible, tense' or qualitative $>$ quantitative, whereas analogous use of adjectives in phrases is fairly common: Rutuga tulete kaudu, nii tuline rutt oo et 'You rush here, so hotfoot that...'; Poisid külas riidu läind, üks jooseb ies, sellel tuline hirm taga, ep teegid kohes ta enese matab 'The boys in the village started a fight, one is running ahead, in fiery panic, don't even know where he falls'; Oh sa tuline silk! 'Oh, you hot herring!'; Oh sa tuhat tuline kurat! 'Oh, you fiery devil!' / 'Damn it!'; Oh sa tuhat ja tuline, kui ma ta kätte saa 'Deuce it, if I don't catch him!'

- If 'wind' as source domain corresponds to someone who does something quickly as target domain, then it is understood through mapping THE SPEED OF ACTION IS THE SPEED OF THE MOTION OF AIR: Tull kui tuuluspää tüü mano, robot läts jälke uma tiid 'Came like a whirlwind to work, then went his way'; No mes ahing sul nü̈̈d küll on taga, et tormad kui tuulispask? 'What is driving you, that you are rushing like a whirlwind?'. The important aspect of target domain here is that acting quickly may result in excessive rushing, pointless hurrying, which does not lead to the intended results. In principle we may group all these metaphors under common metaphor THE SPEED OF PROGRESS IN THE SPEED OF THE MOTION OF AIR or PROGRESS IS THE MOTION OF AIR, with central mapping the speed of motion > the speed of progress. 
- 'justkui tuulispask 'like a whirlwind' is an expression that may be used for a person, who angers quickly and easily: Kiä sääntse väega tulitseide värkkega ja äkilitse omma, sis üldäs, et tu lätt nigu tuulepass vai kadajekõrbeja 'People say about a person who is so fiery and irascible that he goes like a whirlwind or like juniper fire'. Here the projection crucial for understanding the metaphor is INTENSITY OF THE SITUATION IS THE SPEED OF THE MOTION OF AIR.

The use of the same simile, figure of speech, in different but similar meanings demonstrates that acting too rashly is often associated with or explained by a person's restless, impatient, quick-tempered character.

\section{2. 'Air' or 'steam' as source domain of metaphor}

In the following examples the characteristic referred to in the source domain is the quality of different substances to trigger the sense of smell - organisms emit bioactive substances, i.e. smell, to influence individuals of the same species. A source domain may also be a gas containing flowing fluidal particles, i.e. steam, fog.

- Understanding the meaning of simile 'like a smell' denoting 'someone is quickly moving forward' most likely happens through the projection THE SPEED OF MOTION IS THE INTENSITY OF SPREAD, or in more general terms MOTION IS SPREAD: Nuur hobõnõ, laapsa samm, versta kaosõ nigu lõhn 'Young horse, with vigorous step, versts pass like a smell'. Analogous projections may become important when 'smell' stands for 'heat' or 'blaze' of an oven and the source domain of the metaphor is 'fire', cf.: Erk hobune on, öeldaks ka, läheb kui tulepisu 'It is an agile horse, people say, it goes like a fire spark'.

- A projection very similar to the previous one THE INTENSITY OF THE MOTION OF A PERSON IS THE SPEED INTENSITY OF THE SPREAD OF SMELL becomes significant, when the opposed qualities are quickly spreading odor, or smell, and a lively person moving around: Salt nigu piir sõglan, ei püsü paigal 'You're like a bad smell in a sieve, cannot stand still'. Interestingly, in some Estonian phrases the words 'air' and 'smell' occur as synonyms, cf. Meil oll jo sääne lõhn takast, et olõ-õs aigu perrägi käia 'We had 
such smell coming behind us, that we had no time to go back' and Ta läheb nii ruttu, et ohk taga' He goes so quickly that has air behind him', also öhk juures 'air around him' - 'the bad smell disappears quickly'.

- With the meaning 'someone quickly leaves, disappears', similes kui lõhn, kaob kui kaste 'like a smell, disappears like dew' represent the metaphor A PERSON'S DEPARTURE IS DISPERSION OF A SMELL DEW: Läts ku lõhnati, kae-es perrägi 'Left like a smell, didn't even look back'; Imä tahtse minu pessä, ma anni jalule tedä, siss ol kaonu nigu hommugune hall 'That wanted to hit me, I gave one in the legs, then was gone like morning dew'. In addition to great speed, an important aspect of these target domains, emphasised by source domains, is perhaps finality, completion: $S a$ kaud ära kui kaste, et nimigi ei jää 'You disappear like morning dew, not even a name is left behind'; kaduma ku kaste 'disappear like morning dew' 'tuleb ja kaub ära, raha kulub ruttu ära või külaline kaub ruttu, jälge ei jää 'comes and disappears, money is quickly spent or a visitor leaves quickly, without a trace'; Kui Juhan kuulis, et Leenal laps tulemas, kadus kut kaste 'When Juhan heard that Leena was with child, he disappeared like morning dew'; Kaddugu sa nenda maa peält, kut kaste rohu peält! 'May you disappear from their lands, like a morning dew from the grass!'. The same aspect is referred to by the use of the 'smell'-figure in expressions of different meanings: Kausitäüs ruuga läts ku lóhnati 'A bowlful of food went [was eaten] like a smell'; Küll ta lõbib, nii et kauss om tühi nigu lõhn jälle 'Oh, he will devour so that his bowl will soon be empty like a smell'; Temäl om varsti nigu lõhn kõik meelest lännu 'He will forget everything like smell'; Sai püsi kah üits lõhn paegal, oled kõik aig nigu nõgeste sehen, et kõrvetedas takast 'You are like a smell, can't stay still, you are like in nettles all the time, with your back in nettle-rash'; Küll om inimene, ei häbene mitte üits lõhn, liperdäp egäl puul 'What a person, is not shamed one smell, idles everywhere'; Lätsi kinni võtma, a vargist olõs inäp nuhkugi 'Went to catch him, but there was not one sniff of the thief'.

- Similes kaob kui kaste, puss tuulõ pääl 'disappears like morning dew, smell in the wind' may also mean 'something is ending, is quickly running out', thus presenting the metaphor THE SPEED OF ENDING IS THE SPEED OF DISPERSING OF STEAM OR A 
SMELL. Here an important aspect is the value of the target domain, i.e. food, commodities, clothes, money, fortune: Kui puss tuulõ pääle 'kraami jaga ar' 'the things were divided' like a bad smell in the wind', cf. kaob kui kaste 'disappears like morning dew', meaning 'the visitor leaves quickly, soon' above. Consider also similes with close meanings nagu tilk vett kuumale kerisele 'like a drop of water on hot sauna oven'; Meitid on na palju inimesi, et toit kaub nagu vesi kuuma kibi peale 'There are so many of us that food disappears like water on hot stones' and läks kui kerisele 'went like on a hot sauna oven': Mu lehmäl lätt küll kiik sisse, olgu vai akan, kiik lätt ku keressele 'My cow ate everything, chaff and all, everything went like on a sauna oven'.

\section{3. 'Sound' as source domain of metaphor}

In some similes the source of metaphor is sound, i.e. mechanical vibrations transmitted in the form of waves through air.

- The understanding of the expression tuleb nagu püssipauk 'comes like a gunshot', meaning 'someone or something is coming, appearing quickly, unexpectedly', may be based on the metaphor THE INTENSITY OF A SITUATION IS THE INTENSITY OF A SOUND: tuli nagu püssipauk kaela 'kui vahest kellegil inimesel mõni rutuline sõnum on tulnud, nii et enne veel selle vastu valmistada ei teadnud' 'came like a gunshot, if some person received an unexpected message, that he could not prepare himself for". It is possible, that in terms of target domain the event does not only have to happen quite quickly, but has to be accompanied by some noise, cf. Saa äkki kurjas nõndagu püssipauk, Sa oled õige püss! 'Suddenly grew angry like a gunshot, You are some gun!', Kis söuse püssiga rääkida saab 'How can you talk to such a gun'; Uo eldus, läks vihale, kus hakkas käristama nigu kuulipritsist, ma jõudand vahele nohhgi üelda 'Oh dear, got angry and started rattling like a machine-gun, I could not say a thing' meaning 'an angry, quick-tempered person, who quarrels loudly, shouts'.

Generally speaking, we may agree that most metaphoric inferences presented here are based on the central mapping the speed $\sim$ intensity of the motion of air > intensity of a situation, in the course of which the main meaning focus - which is on the intensity of a situ- 
ation - of source domain to target domain. The 'air' metaphors mentioned above A PERSON IS A WIND; A PERSON or A THING IS A SMELL; ACTIVITY IS A SMELL; A PERSON IS A SOUND; A MESSAGE, NEWS IS A SOUND may be regarded as complex metaphors, i.e. these metaphors are composed of the simple or primary metaphor THE INTENSITY OF A SITUATION IS THE SPEED INTENSITY OF THE MOTION OF AIR - this central mapping is the basis of a number of other mappings and metaphoric inferences. Thus complex metaphors consist of simple metaphors that function as mappings and not the other way around.

\section{CONCLUSION}

Although the number of the phrases discussed in this article are relatively limited, their analysis indicates to a large number of possible manifestations of the concept kiiresti, or 'quickly' in the Estonian language. The concept is used in describing the physical movement of a body in space as well as the mental movement associated with perception. The majority of the described similes characterise dynamic progressive or non-progressive situations, the relationship between progress and viewpoint of the situation in the similes may be either specified or unspecified. Similes describing static situations point to characteristically human qualities. Similes are very often used to express that someone moves/acts or something moves/ happens too quickly - the negative attitude of the speaker is clearly detectable. The understanding of the majority of similes is based on metaphoric correspondences, or mappings. The source domain of a metaphor is often an animal or a typically quickly occurring phenomenon of nature, the target domain of a metaphor is usually a person. The systematic projection discussed in the article may, perhaps, be regarded as manifestations of naive physics in language, which occurs among other general popular naïve theories reflected in language. The semantic variations presented here clearly represent the inherent tendencies of metaphoric mappings - be it the speaking of mental processes through the physical or conceptualising abstract phenomena through the specific. 


\section{References}

Akhmanova, Ol'ga Sergeevna 1969. Slovar' linguisticheskikh terminov: [Okolo 7000 terminov]. Izd. 2-e stereotip. Moskva: Sovetskaia entsiklopedia.

Apresian $=$ Apresian, Yurii Derenikovich \& Boguslavskaia, O. Yu. \& Krylov, T. V \& Levontina, E. V. \& Uryson, V. Yu. \& Apresian, V. Yu. \& Babaevka, E. Ye. \& Glovinskaia, Ya. \& Grigor'eva, S. A. \& Ptentsova, A. V. 2000. Novyi ob'iasnitelnyi slovar' sinonimov russkogo iazyka. Studia philologica (Moscow, Russia). 2nd ed. Moskva: Shkola "Yazyki russkoi kul'tury".

EKMS = Saareste, Andrus 1958-1963. Eesti keele mõisteline sõnaraamat = Dictionnaire analogique de la langue estonienne: Avec un index pourvu des traductions en francais I-IV. Eesti Teadusliku Seltsi Rootsis väljaanne 3. Stockholm: Vaba Eesti.

Krikmann, Arvo 2002. Veel mõni sõna metonüümiast [Further Considerations on Metonymy]. Herlin, Ilona et al. (eds.). Äidinkielen merkitykset. Suomalaisen Kirjallisuuden Seuran toimituksia 868. Helsinki: Suomalaisen Kirjallisuuden Seura, pp. 575-592.

Krikmann, Arvo 2003. Kaasaegse metafooriteooria panus parömioloogiasse. Krikmann, Arvo (ed.). Uurimusi folkloori lühivormidest [Paremiology and Contemporary Theory of Metaphor. Studies into the short forms of folklore]. Reetor 1. Tartu: Eesti Kirjandusmuuseum, pp. 52-144.

Kövecses, Zoltán 2000. The Scope of Metaphor. Barcelona, Antonio (ed.). Metaphor and Metonymy at the Crossroads: A Cognitive Percpective. Topics in English linguistics 30. Berlin \& New York: Mouton de Gruyter, pp. 79-92.

Kövecses, Zoltán 2002. Metaphor: A Practical Introduction. Oxford: Oxford University Press.

Lakoff, George \& Johnson, Mark 1980. Metaphors We Live By. Chicago: The University of Chicago Press.

Lakoff, George \& Turner, Mark 1989. More than Cool Reason: A Field Guide to Poetic Metaphor. Chicago: University of Chicago Press.

Metslang, Helle 1997. Maksimaalsuse ja minimaalsuse väljendamisest eesti püsiühendites [On expressing maximum and minimum in Estonian set phrases]. Erelt Mati \& Sedrik, Meeli \& Uuspõld, Ellen et al. (eds.). Pühendusteos Huno Rätsepale [Dedicated to Huno Rätsep]: 28.12.1997: [keeleteadlase 70. sünnipäevaks. Tartu Ülikooli Eesti Keele Õppetooli toimetised 7. Tartu: Tartu Ülikooli Kirjastus, pp. 139-154.

Tragel, Ilona 2003. Eesti keele tuumverbid [Core Verbs in the Estonian Language]. Dissertationes linguisticae Universitatis Tartuensis 3. Tartu: Tartu Ülikooli Kirjastus.

Vainik, Ene 1995. Eesti keele väliskohakäänete semantika: Kognitiivse grammatika vaatenurgast [Semantics of External Location Inflections in Estonian Language from the Aspect of Cognitive Grammar]. Tallinn: Eesti Teaduste Akadeemia Eesti Keele Instituut. 
Õim, Asta 1991. Sünonü̈̈misõnastik [Dictionary of Synonyms]. Tallinn: Asta Õim.

Õim, Asta 2002. Leksikaalsete sünonüümide sisulisest küljest [On the content of lexical synonyms]. Kallasmaa, Marja \& Langemets, Margit (eds.). Nime murre: Pühendusteos Valdek Palli 75. sünnipäevaks 30. juunil 2002. [Dialectal Name. Dedicated to the 75th birthday of Valdek Pall, June 30, 2002]. Eesti Keele Instituudi toimetised 11. Tallinn: Eesti Keele Sihtasutus, pp. 292-315.

Õim, Haldur 1997. Eesti keele mentaalse maailmapildi allikaid ja piirjooni [The sources and principles of the mental worldview in the Estonian language]. Erelt Mati \& Sedrik, Meeli \& Uuspõld, Ellen et al. (eds.). Pühendusteos Huno Rätsepale [Dedicated to Huno Rätsep]: 28.12.1997: [keeleteadlase 70. sünnipäevaks. Tartu Ülikooli Eesti Keele Õppetooli toimetised 7. Tartu: Tartu Ülikooli Kirjastus, pp. 255-268. 